Available online at: https://proceeding.researchsynergypress.com/index.php/cpmhs/index

RSF Conference Series: Medical and Health Science

e-ISSN (to be processed) / p-ISSN (to be processed)

Volume 1 Number 1 (2021): 91-96

\title{
Relationship Between Dietary Approach to Stop Hypertension (DASH) Knowledge and Hypertension
}

\author{
Fajar Awalia Yulianto', Eka Nurhayati' ${ }^{1}$ Ahmadillah Firdaus ${ }^{2}$, Y. Elfi ${ }^{3}$ \\ ${ }^{1}$ Public Health Department, Faculty of Medicine, Universitas Islam Bandung, Indonesia \\ ${ }^{2}$ Faculty of Medicine, Universitas Islam Bandung, Indonesia \\ ${ }^{3}$ Puskemas Cinunuk, Bandung District, Indonesia
}

\begin{abstract}
The prevalence of non-communicable hypertension in Indonesia in 2007, 2013, and 2018 tends to increase. This phenomenon is predicted to continue. Riskesdas shows that the prevalence of hypertension in 2018 shows the number in the population aged over 18 years based on national measurements of $34.11 \%$. Based on the annual report of the Cinunuk Public Health Center, it shows that hypertension is the largest non-communicable disease pattern in the Cinunuk Public Health Center in 2020, reaching 2672 cases of disease from 12517 cases of other diseases with a percentage of $21.34 \%$. Hypertension is still a major public health problem associated with considerable morbidity and mortality. Hypertension can be controlled consistently by modifying a healthy lifestyle. The DASH (Dietary Approach To Stop Hypertension) dietary intervention recommended in national guidelines can substantially lower blood pressure in both people with hypertension and those without hypertension. This study aims to determine the relationship between knowledge of DASH (Dietary Approach To Stop Hypertension) and hypertension in Cinunuk village in 2021. This study was conducted using a quantitative method with a cross-sectional approach using primary data obtained through google form distribution. The research subjects were the people of Cinunuk Village, Cimekar, a total of 103 respondents who met inclusion and exclusion criteria. The results of this study indicate that there is a relationship between Knowledge of DASH and Hypertension in Cinunuk Village (P 0.049), where the hypertension proportion was significantly smaller $(2.6 \%)$ than the no-hypertension percentage $(15.6 \%)$ in the group who familiar with DASH. Lifestyle modification, including DASH, play an important role in controlling hypertension.
\end{abstract}

Keywords: Blood Pressure, DASH Diet, Hypertension

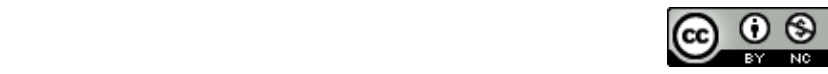

This is an open access article under the CC-BY-NC license

\section{INTRODUCTION}

Hypertension is a non-communicable disease that is responsible for premature death in the world (Kementrian Kesehatan Republik Indonesia, 2018). It is characterized by systolic blood pressure equal to or more than $140 \mathrm{mmHg}$ and diastolic equal to or more than $90 \mathrm{mmHg}$ (Pusat Data dan Informasi Kementrian Kesehatan Republik Indonesia, 2014). In 2019, the prevalence of hypertension globally was $22 \%$ of the total world population. However, less than a fifth number of patients control their blood pressure routinely (Kementrian Kesehatan Republik Indonesia, 2018). Hypertension is still a world health problem that is urgent to be controlled (World Health Organization, 2020).

The prevalence of hypertension in Indonesia, according to the 2018 National Basic Health Research (RISKESDAS), was $34.11 \%$ in over 18 years old group, increased according to age with the proportion of $13.2 \%, 45.3 \%$, and $69.5 \%$ in patients aged $18-24$ years, $45-54$ years, and 75 years respectively. West Java, as the densest province in Indonesia, occupied the 2nd largest hypertension prevalence of $39.60 \%$ Corresponding author Fajar Awalia Yulianto, awalia.yulianto@gmail.com; Eka Nurhayati, nurhayatieka1@gmail.com DOI: (to be processed) 
(Kementrian Kesehatan Republik Indonesia, 2018). Dwell deeper, The Health Profile from the West Java Health Office in 2017 showed the city of Bandung has a hypertension prevalence of $34.9 \%$ and is situated at the 5th place after other districts/cities in the province (Dinas Kesehatan Provinsi Jawa Barat, 2017).

Hypertension is still a major health problem in the community associated with considerable morbidity and mortality (Rodeheffer, 2011). According to the annual report of the Cinunuk Public Health Center, hypertension is the largest non-communicable disease that consistently dominates the outpatient visit at the Cinunuk Public Health Center (Puskesmas Cinunuk, 2020).

This disease can be controlled consistently by modifying a healthy lifestyle. A report from the Joint National Committee 7 (JNC 7) on the prevention, detection, evaluation and treatment of high blood pressure recommended all individuals with a blood pressure of $120 / 80 \mathrm{mmHg}$ or more should adopt healthier lifestyle modifications to help prevent or manage hypertension (National Institute of Health, 2003). Dietary interventions have become the mainstay of non-pharmacological therapies focused on salt restriction and weight loss. The success of these interventions is usually less adequate, largely due to difficulties in achieving and maintaining healthy dietary and lifestyle changes.

The Dietary Approaches to Stop Hypertension (DASH) method is recommended in national guidelines to control hypertension. The diet emphasizes consumption of fruits, vegetables, and low-fat dairy products such as whole grains, poultry, fish, and nuts, legumes; combined with little red meat, sweets, sugary drinks, and low amounts of total and saturated fat and cholesterol that aim to lower blood pressure substantially in both people with hypertension and those without hypertension (Conlin et al., 2003). The combined DASH dietary intervention with weight control reduces the blood pressure value by $16.1 / 9.9 \mathrm{mmHg}$ (Blumenthal et al., 2010).

\section{LITERATURE REVIEW}

Hypertension classification according to the Joint National Committee (JNC) 7 summarized in Table 1.

Table 1. Blood Pressure Classification

\begin{tabular}{lll}
\hline $\begin{array}{c}\text { Blood pressure } \\
\text { classification }\end{array}$ & \multicolumn{1}{c}{$\begin{array}{c}\text { Systolic Blood Pressure } \\
\text { (mmHg) }\end{array}$} & \multicolumn{1}{c}{$\begin{array}{c}\text { Diastolic Blood Pressure } \\
\text { (mmHg) }\end{array}$} \\
\hline Normal & $<120$ & $<80$ \\
Prehypertension & $120-139$ & $80-89$ \\
Stage 1 Hypertension & $140-159$ & $90-99$ \\
Stage 2 Hypertension & $\geq 160$ & $\geq 100$ \\
\hline
\end{tabular}

Hypertension is related to cardiovascular diseases. The higher the blood pressure, the greater risk of having cardiovascular diseases such as heart attack, heart failure and can lead to death. Hypertension is also related to other diseases such as stroke or kidney failure. It is important to lowering blood pressure in order to keep healthy. One of many ways to maintain normal blood pressure is through a healthy diet (National Institute of Health, 2003).

Dietary Approaches to Stop Hypertension (DASH) eating plan is one of many healthy diets that have targeted maintaining healthy blood pressure. It was originally developed in the 1990s. In pilot research in 1992, It was proven that DASH could reduce systolic blood pressure by 6 to $11 \mathrm{mmHg}$. Researchers recommend DASH as the first-line pharmacologic therapy along with lifestyle modification (Challa et al., 2021). 
Dietary Approaches to Stop Hypertension (DASH) promotes the consumption of fruit, vegetables, whole grains, fish, poultry, beans, seeds, and nuts. It is also suggested to consume less sodium, sweets, fat, and red meat. People who practice DASH can still consume milk products, but the fat-free or low-fat ones. It also contains less saturated fat, trans fat, and cholesterol but is rich in micronutrients such as potassium, magnesium, calcium, protein, and fiber (National Institute of Health, 2015). An example serving guide of DASH per day are 1) five servings of vegetables; 2) five meals of fruit; 3) seven servings of carbohydrates; 4) two servings of low-fat dairy products; 5) two servings of lean meat products, and 6) two to three times of nut and seed in a week (Challa et al., 2021).

Studies have revealed that DASH helps not only lowering blood pressure but also lowering blood glucose, triglycerides, and LDL-C. It is also effective as a weight reduction program (Challa et al., 2021; National Institute of Health, 2015). Thus, many physicians recommend the DASH diet to prevent and tackle non-communicable diseases combined with physical activity and pharmacological management (Challa et al., 2021).

\section{RESEARCH METHODOLOGY}

This cross-sectional study was conducted at the Cinunuk Health Center from July to August 2021. DASH questionnaire was collected through a google form that was distributed to the community around the health center in a purposive sampling approach. The respondents must meet eligibility criteria to be involved in this study.

Inclusion criteria:

- Above 18 years old

- Located in the neighboring area of the health center

- Visit the health center

Exclusion criteria:

- Refuse the consent

- Skip mandatory questions

Figure 1. Respondents Eligibility Criteria

There were 103 eligible respondents in this study, located from three villages around the health center. People who visited the center were asked to fill the form themselves while accompanied by the data collector in case questions arose. The form was sent and collected as a spreadsheet. Non-parametric hypothesis testing was chosen to analyze the relationship between knowledge of DASH diet and hypertension.

\section{FINDINGS AND DISCUSSION}

The results of the study on the characteristics of participants based on gender, age, last education, occupation, length of stay in Cinunuk/Cimekar. 
Table 2. Characteristics frequency

\begin{tabular}{lll}
\hline Characteristics & n & \% \\
\hline Sex & & \\
$\quad$ Male & 36 & 35 \\
$\quad$ Female & 67 & 65 \\
\hline Age & & \\
17-35 years & 19 & 18 \\
36-55 years & 56 & 55 \\
$\quad>55$ years & 28 & 27 \\
\hline
\end{tabular}

\section{Last education}

Elementary school $\quad 3 \quad 3$

$\begin{array}{lll}\text { Junior High School } & 7 & 7\end{array}$

High School $27 \quad 26$

University $66 \quad 64$

\begin{tabular}{lll}
\hline Profession & & \\
Civil servant & 33 & 32 \\
Non Civil servant & 24 & 23 \\
Business & 13 & 13 \\
Education & 5 & 5 \\
$\quad$ Unemployed & 28 & 27 \\
\hline Stay duration & & \\
$1-3$ years & 1 & 1 \\
$>3$ years & 102 & 99 \\
\hline Total & 103 & 100
\end{tabular}

Most respondents were female, aged between 36 to 55 years old, with last education in university. They were working as a civil servant and resided for more than three years in the area. Unfortunately, table 3 describes DASH as not popular among the respondents. There were only nine subjects who recognized DASH diet.

Table 3. DASH knowledge frequency

\begin{tabular}{cll}
\hline DASH & $\mathbf{n}$ & $\mathbf{\%}$ \\
\hline Recognize & 11 & 9 \\
Unfamiliar & 92 & 91 \\
\hline Total & 103 & 100 \\
\hline
\end{tabular}

Tabel 4. Blood Pressure frequency

\begin{tabular}{llcc}
\hline Blood pressure category & $\begin{array}{c}\text { Systolic/ } \\
\text { Diastolic (mmHg) }\end{array}$ & $\begin{array}{c}\text { Frekuensi } \\
\text { (n) }\end{array}$ & $\begin{array}{c}\text { Percentage } \\
\text { (\%) }\end{array}$ \\
\hline Normal dan Prehipertensi & $<120-139 /<80-89$ & 64 & 62 \\
Hipertensi & $\geq 140 / \geq 90$ & 39 & 38 \\
\hline
\end{tabular}


RSF Conference Series: Medical and Health Science, Vol. 1 (1), 91-96

Relationship Between Dietary Approach to Stop Hypertension (DASH) Knowledge and Hypertension

Fajar Awalia Yulianto, Eka Nurhayati, Ahmadillah Firdaus, Y. Elfi

\begin{tabular}{lll}
\hline Total & 103 & 100 \\
\hline
\end{tabular}

The Prehypertension group was combined with the normal group to meet the chi-square requirement regarding the cell number in bivariable analysis. $38 \%$ of subjects were hypertension.

Table 5. Cross-tabulation of DASH and hypertension

\begin{tabular}{lllll}
\hline & \multicolumn{2}{l}{ Hypertension } & Total & P- \\
\cline { 2 - 4 } & No & Yes & & Value \\
\hline Diet DASH & & & & \\
Recognize & $10(15,6 \%)$ & $1(2,6 \%)$ & $110,7 \%)$ & 0 \\
Unfamiliar & $54(84,4 \%)$ & $38(97,4 \%)$ & $92(89,3 \%)$ & \\
\hline Total & $64(100 \%)$ & $39(100 \%)$ & $103(100 \%)$ & \\
\hline
\end{tabular}

In the group who recognized DASH diet, the hypertension proportion was significantly smaller compared to the no hypertension percentage. In the other group, the unfamiliar one, the hypertension proportion was significantly larger than non-hypertension. In other words, the possibility of hypertension was slighter when the subject knew what should and should not eat according to the DASH diet.

In this study, the knowledge variable DASH (Dietary Approach To Stop Hypertension) had a relationship with the incidence of hypertension ( $\mathrm{p}=0.049)$. Table 5 shows that out of 11 people who have knowledge of the DASH diet, only one person has hypertension and ten others have normal blood pressure. The results of this study are in line with the study of Frank MS et al. where the application of the DASH dietary intervention with consumption of low sodium levels ( $50 \mathrm{mmol} /$ day) caused an average 7.1 $\mathrm{mmHg}$ lower systolic blood pressure in respondents without hypertension, and $11.5 \mathrm{mmHg}$ lower in respondents with hypertension (Sacks et al., 2001).

The Dietary Approaches to Stop Hypertension (DASH) intervention can reduce blood pressure substantially in both people with hypertension and those without hypertension (Sacks et al., 2001). The Dash diet can lower blood pressure significantly compared to a fruit and vegetable diet that lowers blood pressure by only half of the diet. . Blood pressure measurements were performed over a 24-hour period with an outpatient blood pressure monitor, and the DASH diet was found to lower blood pressure throughout the day. The effect of the DASH diet was particularly pronounced in individuals with stage 1 hypertension, where there was a mean reduction in blood pressure of up to $11.4 / 5.5 \mathrm{mmHg}$ (Craddick et al., 2003).

The DASH diet intervention, in addition to significantly lowering blood pressure, this intervention also showed a decrease in blood cholesterol and homocysteine levels and could increase the benefits and success of antihypertensive drug therapy (National Institute of Health, 2015; Challa et al., 2021). DASH knowledge with hypertension diet compliance in the elderly with hypertension. The better the respondent's level of knowledge, the more obedient to dieting.

The limitation in this study is the time to conduct. The research was short, the respondents were mostly non-community health centers coverage, namely Cinunuk Village and Cimekar Village, and there was a pause due to the emergency PPKM, which interfered with the search for data at the Cinunuk Community Health Center.

\section{CONCLUSION AND FURTHER RESEARCH}

The results showed that there was a relationship between Knowledge of DASH (Dietary Approach To Stop Hypertension) and Hypertension. 


\section{REFERENCES}

Blumenthal, L. J. et al., 2010. Effects of the DASH Diet Alone and in Combination with Exercise and Weight Loss on Blood Pressure and Cardiovascular Biomarkers in Men and Women with High Blood Pressure: The Encore Study. Arch Intern Med, CLXX(2), pp. 126-135.

Challa, H. J., Ameer, M. A. \& Uppaluri, K. R., 2021. DASH Diet to Stop Hypertension. [Online] Available at: https://www.ncbi.nlm.nih.gov/books/NBK482514/. [Diakses 27 August 2021].

Conlin, P. R. et al., 2003. The DASH Diet Enhances the Blood Pressure Response to Losartan in Hypertensive Patients. American Journal of Hypertension, XVI(5), pp. 337-342.

Craddick, S. R. et al., 2003. The DASH Diet and Blood Pressure. Curr Atheroscler Rep, V(6), pp. 484-491.

Dinas Kesehatan Provinsi Jawa Barat, 2017. Profil Kesehatan Provinsi Jawa Barat 2017, Bandung: Dinas Kesehatan Provinsi Jawa Barat.

Kementrian Kesehatan Republik Indonesia, 2018. Riset Kesehatan Dasar 2018, Jakarta: Kementrian Kesehatan Republik Indonesia.

National Institute of Health, 2003. The Seventh Report of the Joint Committee on Prevention, Detection, Evaluation and Treatment of High Blood Pressure. s.l.:U.S. Department of Health and Human Services.

National Institute of Health, 2015. Your Guide to Lowering Your Blod Pressure with DASH. s.l.:National Institute of Health.

Pusat Data dan Informasi Kementrian Kesehatan Republik Indonesia, 2014. Hipertensi. Jakarta: Kementrian Kesehatan Republik Indonesia.

Puskesmas Cinunuk, 2020. Laporan Tahunan Puskesmas Cinunuk Tahun 2020, Bandung: Puskesmas Cinunuk.

Rodeheffer, R., 2011. Hypertension and Heart Failure. Circular American Heart Association, CXXIV(17), pp. 1803-1805.

Sacks, F. M. et al., 2001. Effects on Blood Pressure of Reduced Dietary Sodium and the Dietary Approaches to Stop Hypertension (DASH) Diet. New England Journal Medicine, CCCXLIV(1), pp. 310.

World Health Organization, 2020. Hypertension. [Online]. Available at: https://www.who.int/news-room/fact-sheets/detail/hypertension. [Diakses 19 August 2021]. 